\title{
Sweet Corn Performance and Its Major Nutrient Uptake Following Application of Vermicompost Supplemented with Liquid Organic Fertilizer
}

\author{
Zainal Muktamar ${ }^{\#}$, Sigit Sudjatmiko* ${ }^{1}$, Muhammad Chozin ${ }^{2}$, Nanik Setyowati*3 ${ }^{3}$, Fahrurrozi* $*^{4}$ \\ ${ }^{\#}$ Soil Science Department, University of Bengkulu, Bengkulu 38371, Indonesia \\ E-mail: muktamar1959@yahoo.com \\ *Agronomy Department, University of Bengkulu, Bengkulu 38371, Indonesia \\ E-mail: ${ }^{1}$ slg1t_s@yahoo.com, ${ }^{2}$ _m_chozin@hotmail.com, ${ }^{3}$ nanik_srg@yahoo.com, ${ }^{4}$ rozi38125@yahoo.com
}

\begin{abstract}
Solid organic fertilization in organic farming practices should be supplemented with liquid organic fertilizer to accelerate the availability of plant nutrients. The study aimed to determine performance and major nutrient uptake by sweet corn following application of vermicompost supplemented with liquid organic fertilizer (LOF) and to find out combined vermicompost and liquid organic fertilizer for sweet corn production. The experiment was conducted at CAPS Research Station (1054 m above sea level) from April to June 2016, arranged in split plot design with 5 rates of vermicompost as the main plot and 5 rates of LOF as the subplot. Rates of vermicompost comprised 5, 10, 15, 20, and $25 \mathrm{Mg} \mathrm{ha}^{-1}$, while LOF rates consisted of control, 25, 50, 75, and 100\% (initial concentration). Treatment combination was replicated 3 times. Root application of LOF was carried out every week at 2-8 weeks after planting (WAP) with total volume of $950 \mathrm{ml} \mathrm{plant}^{-1}$. Result pointed out that vermicompost pronouncedly raised nitrogen (N), phosphorus (P) and potassium (K) uptakes and linearly enhanced growth and yield of sweet corn, indicated by plant height, plant leaf area, shoot fresh and dry weight, weight of husked and unhusked ears, diameter of ear, and weight of husked ear per plot but length of ear. The addition of LOF had a similar effect on major nutrient uptake, growth, and yield of sweet corn. Vermicompost at the rate of $25 \mathrm{Mg} \mathrm{ha}^{-1}$ supplemented with $100 \%$ LOF provided greatest growth and yield, suggesting that the fertilizer combination was the most effective complementary organic fertilization for sweet corn production in the organic farming system.
\end{abstract}

Keywords - vermicompost; liquid organic fertilizer; sweet corn

\section{INTRODUCTION}

Organic farming practices have developed quite rapidly in the last decade. This farming practice is believed to be a reliable solution to soil degradation due to prolong application of excessive synthetic fertilizer. Synthetic agrochemical is reported to deteriorate soil fertility, to harm the environment as well as to decrease macronutrient [1]. Long-term application of $\mathrm{N}$ fertilizer leads to significant increase in exchangeable acidity accompanied by a decline in cation exchangeable capacity, base saturation and exchangeable calcium and magnesium [2] as well as decrease soil $\mathrm{pH}$ [3]. Another study also detected that longterm application of synthetic $\mathrm{N}$ fertilizer significantly depleted soil nitrogen [4]. A number of studies confirmed that organic farming by applying organic fertilizer as the only nutrient source had improved soil quality. A study by [5] indicated that organically fertilized soil had higher soil organic carbon and better quality of humic acid as compared to that fertilized with synthetic fertilizer. Soil organic carbon and carbon emission were also reported higher with an application of organic amendment in calcareous soil [6]. Other studies showed that organic farming was also superior in the content of total nitrogen, $\mathrm{NH}_{4}{ }^{+}$, soil $\mathrm{pH}$, microbial carbon and particulate organic matter carbon [7], [8], [9], [10]. The addition of $\mathrm{N}$ fertilizer to organic fertilization, however, did not provide an effect of total soil nitrogen of Ultisol as reported by [11].

Vermicompost is commonly used as a source of plant nutrient in organic farming system. This particular organic fertilizer has an additional benefit to soil fertility and plant growth due to its content of nutrient as well as plant regulator and hormones. Vermicompost from coffee pulp using exotic earthworm (Eudrilus eugeniae) contained $14.67 \%$ organic-C, $1.66 \% \mathrm{~N}, 0.41 \% \mathrm{P}, 0.70 \% \mathrm{~K}, 0.52 \% \mathrm{Ca}$, $0.31 \% \mathrm{Mg}$ and $\mathrm{pH}$ of 7.21 [12]. Other study showed that vermicompost from cattle manure and green forage had 
higher microbial biomass carbon, dehydrogenase activity, urease activity, and phosphatase activity, in comparison to control [13]. A study by [14] indicated that vermicompost was superior to buffalo manure and compost to reduce runoff, soil erosion, and nitrate leaching.

Organic fertilizer, however, releases plant nutrient slowly so that nutrient is often not available for plant growth when required. During the growth period, organic fertilizer releases nitrogen, phosphorus, and potassium only $50 \%$ of its potential [15]. A study by [16] confirmed that slow release of plant nutrient leads to better plant growth in long term. Supplement of nutrient is necessary to accelerate its availability for plant growth. Liquid organic fertilizer is commonly used by the regular farmer in Indonesia for additional nutrient availability during plant growth period. For instance, nitrogen from liquid organic fertilizer is available immediately after application [17].

Liquid organic fertilizer is commonly prepared from animal wastes, green biomass or combination of both. The nutrient content of liquid organic fertilizer is mainly dependent on the nutrient content of its sources. Liquid organic fertilizer from dairy cattle effluent contains $318 \mathrm{mg}$ $\mathrm{l}^{-1}$ total carbon, $60 \mathrm{mg} \mathrm{l}^{-1}$ total nitrogen, $4 \mathrm{mg} \mathrm{l}^{-1}$ phosphorus, $700 \mathrm{mg} \mathrm{l}^{-1}$ potassium, and $\mathrm{pH}$ of 6.2 [18]. Other researcher reported that liquid organic fertilizer contained much higher content of carbon (1.44\%), total nitrogen (2.52\%), phosphorus $(0.14 \%)$, potassium (1.69\%) and lower $\mathrm{pH}(5.80)$ [19]. Application of liquid organic fertilizer is reported to improve soil quality. Column study conducted by [20] pointed out that liquid organic fertilizer increased $\mathrm{N}-\mathrm{NO}_{3}$, available $\mathrm{P}$, exchangeable $\mathrm{K}$, soil $\mathrm{pH}$ and decreased exchangeable Al up to the depth of $20-25 \mathrm{~cm}$ but available $\mathrm{P}$ which is only to the depth of $10-15 \mathrm{~cm}$ from the soil surface. The similar result reported by [15] that nitrate moved downward to a much lower depth $(150-180 \mathrm{~cm})$. However, [21] found out that liquid organic fertilizer had no effect on soil quality indicators.

In addition to improvement of soil quality, liquid organic fertilizer also has no or significant effect on growth and yield of crops. Application of liquid organic fertilizer has no effect on growth and yield of carrot [22], but significantly reduces the time of tasselling, increases grain yield of corn [23]. Previous studies also indicated that liquid organic fertilizer significantly provided better growth and yield of sweet corn [24], [18], [25]. However, [26] concluded that growth and yield of sweet corn were not affected by local based liquid organic fertilizer. Application of liquid organic fertilizer has been confirmed to increase sweet corn uptake of nitrogen but phosphorus and potassium. The increase in nitrogen uptake is not followed by an increase in yield of sweet corn [27]. The study aimed to determine performance and major nutrient uptake by sweet corn following application of vermicompost supplemented with liquid organic fertilizer (LOF) and to find out combined vermicompost and liquid organic fertilizer for sweet corn production.

\section{MATERIALS AND METHODS}

\section{A. Site Description and Soil Amendment}

The field experiment was carried out in sandy loam, soil suborder of Andept at Closed Agricultural Production
System (CAPS) Research Station from April to June 2016. The research station was located in Air Duku Village, Rejang Lebong, Bengkulu Province, Indonesia at a longitude between $102^{\circ} 36^{\prime} 54.96 " \mathrm{E}$ and $102^{\circ} 36^{\prime} 56.82^{\prime \prime} \mathrm{E}$ and a latitude between $3^{\circ} 27^{\prime} 34.26^{\prime \prime} \mathrm{S}$ and $3^{\circ} 27^{\prime} 37.02^{\prime \prime} \mathrm{S}$ at an elevation of $1054 \mathrm{~m}$ above sea level. Average monthly rainfall was $233.75 \mathrm{~mm}$ per month with no dry month according to Smith and Ferguson climate classification. Throughout the growing season, mean soil temperature at a depth of $20 \mathrm{~cm}$ was $23-24^{\circ} \mathrm{C}$. The experimental plots were established in early 2014 on long- term experimental site for the study of soil quality dynamics and crop production in the organic farming system.

The initial composite soil sample was collected from 0-20 $\mathrm{cm}$ depth in February 2014 using a soil probe. Surface soil contained $20.5 \mathrm{~g} \mathrm{~kg}^{-1}$ total organic-C, $1.9 \mathrm{~g} \mathrm{~kg}^{-1}$ total soil nitrogen $(\mathrm{N}), 5.54 \mathrm{mg} \mathrm{kg}^{-1}$ available phosphorus $(\mathrm{P}), 0.11 \mathrm{~g}$ $\mathrm{kg}^{-1}$ potassium $(\mathrm{K}), 0.98 \mathrm{~g} \mathrm{~kg}^{-1}$ calcium $(\mathrm{Ca}), 0.05 \mathrm{~g} \mathrm{~kg}^{-1}$ magnesium (Mg), $0.13 \mathrm{~g} \mathrm{~kg}^{-1}$ aluminum (Al), $14.32 \mathrm{cmol} \mathrm{kg}^{-}$ ${ }^{1}$ Cation Exchange Capacity (CEC) and soil pH of 4.83 . From 2011 to 2013, the experimental site was continuously cropped to organic vegetables and each season organic fertilizer at a rate of $15 \mathrm{Mg} \mathrm{ha}^{-1}$ was incorporated into the soil. No additional synthetic fertilizer had been applied to the soil. Since 2014, the site was cropped monoculture to organic sweet corn. In November 2015, the experimental site was divided into a number of plots with a treatment of organic fertilizer to study its effect on soil quality dynamic and vegetable crop production. Randomized Block Design was assigned with long-term application of organic fertilizer treatment rates of $5,10,15,20$, and $25 \mathrm{Mg} \mathrm{ha}^{-1}$. The experiment was the second season of the treatment. The first season, the experimental site was cropped to sweet corn.

Vermicompost was prepared using dairy cattle fresh feces incorporated with earthworm (Lumbricus rubellus). Approximately $250 \mathrm{~kg}$ of fresh feces mixed with organic agricultural wastes placed into $4 \times 4 \times 2 \mathrm{~m}^{3}$ roofing block cement and $5 \mathrm{~kg}$ of earthworm was incorporated into the mixture. The mixture was incubated for 8 weeks and kept moist with watering if required. After incubation, vermicompost was sieved with $2 \mathrm{~mm}$ screen and ready for application. Earthworm was put back into the block cement for next vermicompost production. Nutrient content of vermicompost was $255.5 \mathrm{~g} \mathrm{~kg}^{-1}$ organic-C, $21.5 \mathrm{~g} \mathrm{~kg}^{-1}$ total nitrogen, $2.4 \mathrm{~g} \mathrm{~kg}^{-1}$ phosphorus, and $5.5 \mathrm{~g} \mathrm{~kg}^{-1}$ potassium.

Liquid organic fertilizer was prepared by incorporation of materials containing $20 \mathrm{~kg}$ dairy cattle feces, 201 dairy cattle urine, $2 \mathrm{~kg}$ soil containing effective local microorganism, 5 $\mathrm{kg}$ tithonia diversifolia green leaves, $201 \mathrm{EM}-4$ and put into a blue plastic container. Fresh water was added until reaching a total volume of 2001 . The aerobic condition was kept throughout 3-week incubation by providing sufficient air via electric aerator. After incubation, liquid organic fertilizer was screened with cloth, thereafter, it was ready for application. Macronutrient content of liquid organic fertilizer was $2.4 \%$ nitrogen, $0.0144 \%$ phosphorus, and $0.345 \%$ potassium.

\section{B. Experimental Layout and Treatments}

Experimental design was a split plot arrangement of a randomized completely block with three replications. Main 
plots consisted of five vermicompost rates $(5,10,15,20$ and $\left.25 \mathrm{Mg} \mathrm{ha}{ }^{-1}\right)$. Subplots consisted of five liquid organic fertilizer rates $(0,25,50,75$, and $100 \%$, initial concentration). Five main plots of $5 \mathrm{~m} \times 5 \mathrm{~m}$ in each block were constructed a week before planting. The main plot was separated by $50 \mathrm{~cm}$ within the block and $100 \mathrm{~cm}$ between the block. The main plot was divided into 5 subplots ( $1 \mathrm{~m} \mathrm{x} 5 \mathrm{~m}$ ). Vermicompost was incorporated into $0-15 \mathrm{~cm}$ soil surface a week before planting. Top soil application of liquid organic fertilizer was carried out 5 times at 15, 22, 29, 37, and 44 days after planting at the rate of 150, 200, 200, 200, and 200 $\mathrm{ml}$ per plant, respectively. This form of LOF application was selected based on the study by [28] where foliar, and top soil application of liquid fertilizer had no pronounced influence on $\mathrm{N}, \mathrm{P}$, and $\mathrm{K}$ content in corn shoot. Our previous experiment also showed that different forms of fertilizer application had no significant effect on growth and yield of sweet corn.

\section{Field Experiment}

The experimental site was plowed to $20-\mathrm{cm}$ depth using hand-tractor a week before planting. Vermicompost was applied soon after soil tillage. Two sweet corn seeds were planted at a spacing of $70 \times 20 \mathrm{~cm}$. Thinning was carried out 2 weeks after planting. Liquid organic fertilizer was decanted around sweet corn stem to facilitate roots for easily nutrient absorption.

Sweet corn growth variables were measured on five randomly selected plant samples in each subplot at 49 days after planting. Sweet corn leaves were sampled at tasselling (maximum growth). Five ear leaves were collected from randomly selected sweet corn plants in each subplot. Leaf samples were dried at $65-70^{\circ} \mathrm{C}$, ground and analyzed for $\mathrm{N}$, $\mathrm{P}$, and $\mathrm{K}$ content in sweet corn tissues using wet destruction. Major nutrient uptake was calculated by multiplying tissue nutrient content with shoot dry weight. Sweet corn was harvested at 81 days after planting, and yield component variables were measured on sampled plants.

\section{Statistical Analysis}

Analysis of variance was calculated using SAS version 9.1.3 portable at $\mathrm{p}<0.05$. Vermicompost and LOF treatment means were separated using orthogonal polynomial at a probability level of $5 \%$.

\section{RESULTS AND DISCUSSION}

Analysis of variance showed that vermicompost treatment exhibited significant effects on $\mathrm{N}, \mathrm{P}$ and $\mathrm{K}$ uptakes, plant height, leaf area, shoot fresh weight, shoot dry weight, the weight of husked ear, the weight of unhusked ear, ear diameter, the length of the ear and the weight of husked ear per plot. So did LOF treatment. However, vermicompost did not affect the length of the ear while LOF did. The interaction between vermicompost and LOF was observed on most variables except potassium uptake, shoot fresh weight and the weight of unhusked ear (Table 1).
TABLE I

ANALysis OF VARIANCE For GROWTH AND YiELd VARIABles OF SWEET CORN AT P $<5 \%$

\begin{tabular}{|l|c|c|c|}
\hline \multirow{2}{*}{ Variables } & \multicolumn{3}{|c|}{ F< 0.005 } \\
\cline { 2 - 4 } & VCP & LOF & Interaction \\
\hline NUPTAKE & 0.0004 & $<0.0001$ & 0.0512 \\
\hline PUPTAKE & 0.0003 & $<0.0001$ & 0.0113 \\
\hline KUPTAKE & $<0.0001$ & $<0.0001$ & 0.5590 \\
\hline PH & 0.0019 & $<0.0001$ & 0.0105 \\
\hline PLA & 0.0007 & $<0.0001$ & 0.0385 \\
\hline SFW & 0.0008 & $<0.0001$ & 0.1624 \\
\hline SDW & $<0.0001$ & $<0.0001$ & 0.0343 \\
\hline WHE & 0.0006 & $<0.0001$ & 0.0584 \\
\hline WUHE & 0.0002 & $<0.0001$ & 0.3165 \\
\hline LE & 0.0615 & 0.0009 & 0.0169 \\
\hline ED & 0.0020 & $<0.0001$ & 0.0635 \\
\hline YPP & 0.0006 & $<0.0001$ & 0.0588 \\
\hline
\end{tabular}

$\mathrm{VCP}=$ Vermicompost, LOF=Liquid Organic Fertilizer, NUPTAKE $=$ Nitrogen Uptake, PUPTAKE $=$ Phosphorus Uptake, KUPTAKE $=$ Potassium Uptake, $\mathrm{PH}=$ Plant Height, $\mathrm{PLA}=$ Plant Leaf Area, SFW= Shoot Fresh Weight, SDW= Shoot Dry Weight, WHE $=$ Weight of Husked Ear, WUHE= Weight of Unhusked Ear, LE= Length of Ear, ED= Ear Diameter, YPP= Yield per Plot.

\section{A. Nutrient Uptake}

The concentration of $\mathrm{N}, \mathrm{P}$, and $\mathrm{K}$ in sweet corn tissues varied between 1.31-3.34, 0.51-2.47, and 2.29-4.87\%, respectively, which are regarded low to medium concentration for $\mathrm{N}$ and medium to a high concentration of $\mathrm{P}$ and $\mathrm{K}$ [29]. Application of vermicompost and LOF significantly increased $\mathrm{N}, \mathrm{P}$, and $\mathrm{K}$ uptakes as indicated in Figs. 1, 2, and 3. Higher application of vermicompost and LOF exhibited a higher increase in nutrient uptake. Mineralization of compost and LOF releases nutrients to soil; thereafter, available to the plant. Higher application of compost provided higher soil $\mathrm{P}, \mathrm{K}, \mathrm{Ca}, \mathrm{Mg}$ but not $\mathrm{N}-\mathrm{NO}_{3}$ and $\mathrm{S}$ [30]. In another study, soil amended with a higher rate of compost had a higher organic $\mathrm{C}$ and total $\mathrm{N}$ [31].

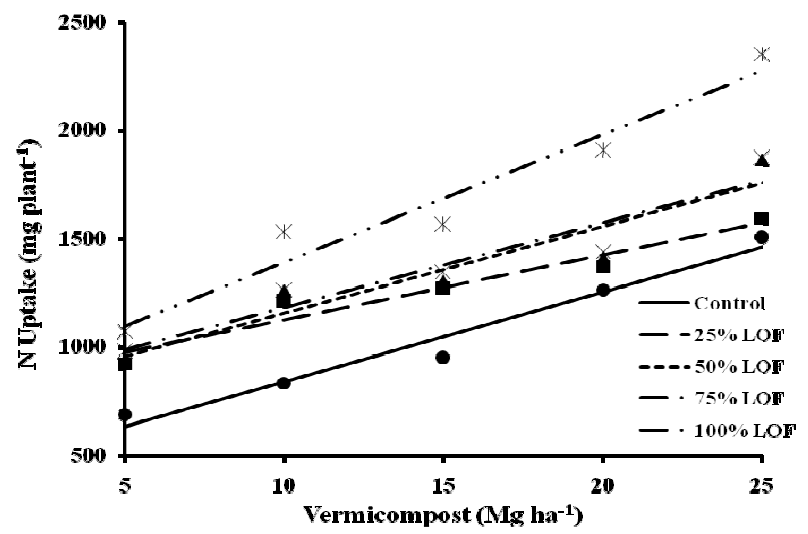

Fig. 1 Nitrogen uptake by sweet corn under application of vermicompost supplemented with LOF

The increase in soil nutrient leads to higher nutrient uptake by sweet corn. The previous study showed that corn tissues concentration and uptake of $\mathrm{P}$ and $\mathrm{K}$ in no-tillage and chisel tillage pronouncedly increased when fertilized with $\mathrm{P}$ and $\mathrm{K}$ fertilizer [32]. Application of compost raised $\mathrm{K}$ uptake but reduced $\mathrm{Ca}$ and $\mathrm{Mg}$ uptakes by corn [33]. Another study concluded that $\mathrm{N}$ fertilization increased $\mathrm{N}$, and $\mathrm{K}$ but had no effect or decreased $\mathrm{P}$ removal by corn cultivated in a number of sites in the State of Minnesota, USA [34]. Significant 
increase in $\mathrm{N}$, $\mathrm{P}$, and $\mathrm{K}$ uptakes of corn was also observed when higher compost rates were applied to tropical soil of Nigeria [35].

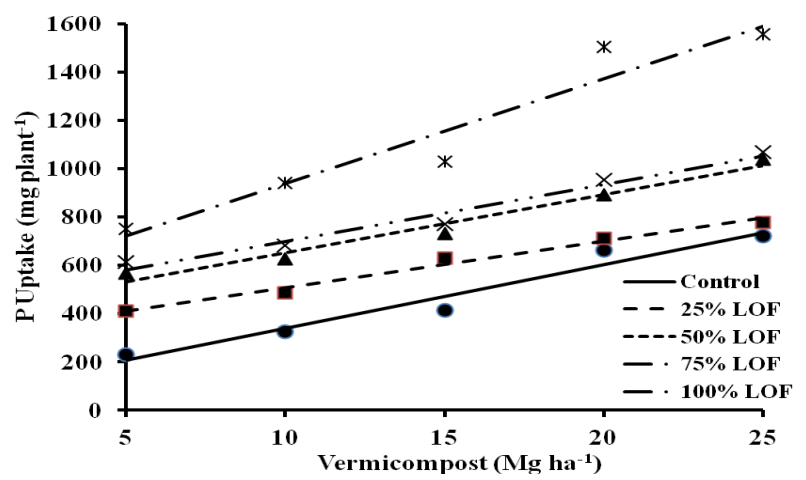

Fig. 2 Phosphorus uptake by sweetcorn as affected by vermicompost fertilization combined with LOF

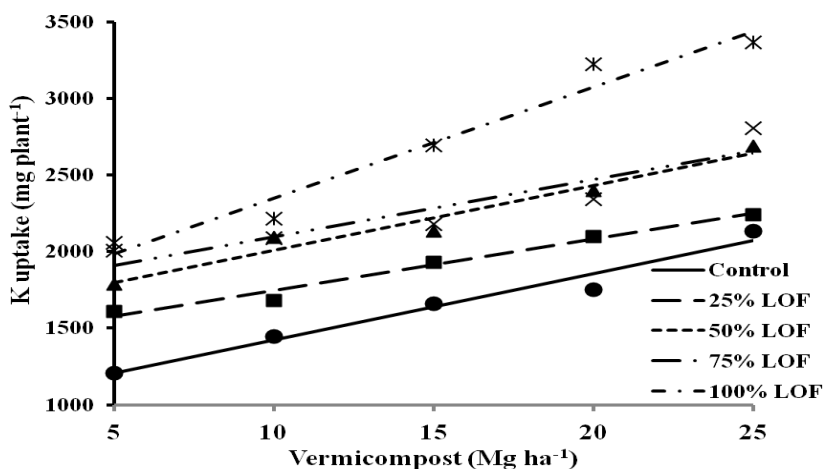

Fig. 3 Potassium uptake by sweet corn as influenced by vermicompost fertilization combined with LOF
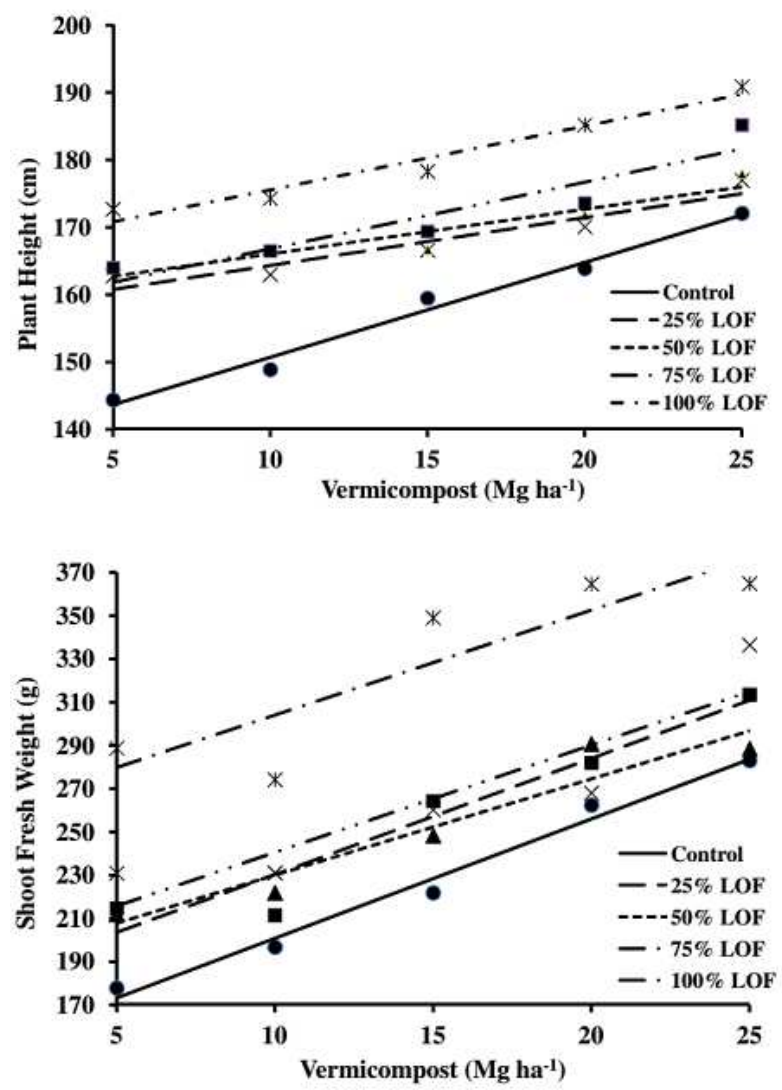

Fig. 4 Vermicompost and LOF combination effects on plant height, plant leaf area, shoot fresh and dry weight fertilization for major nutrient uptake.
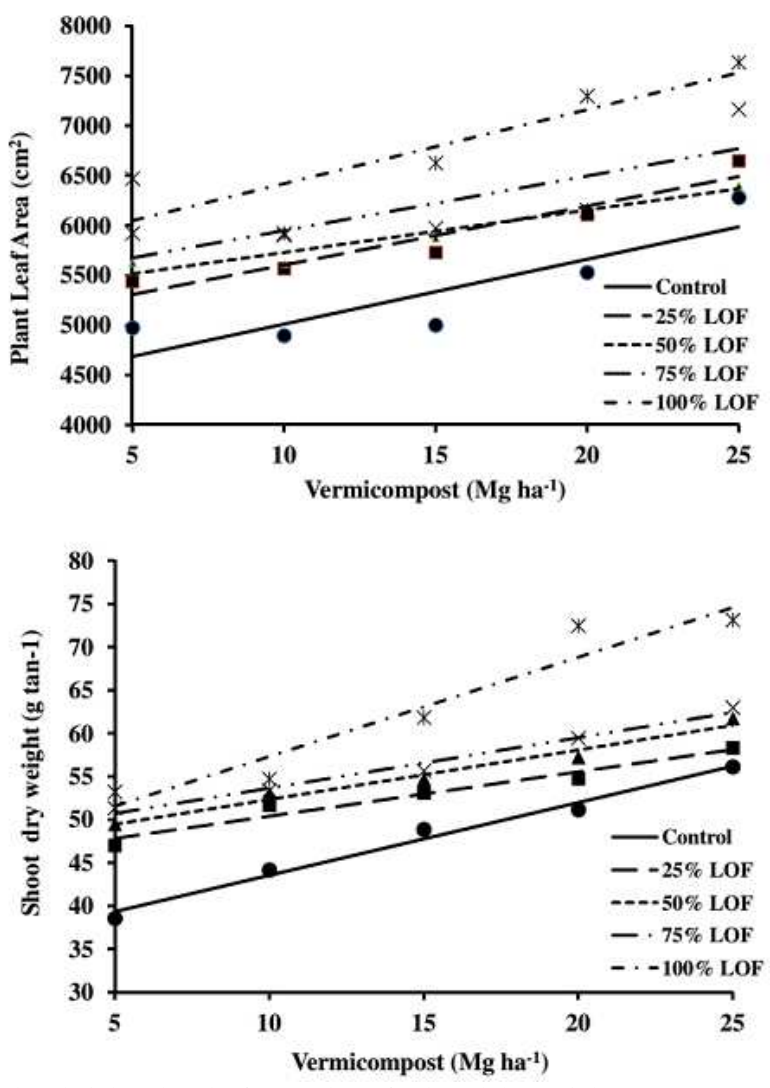

Supplement of LOF considerably raised sweet corn uptakes of $\mathrm{N}, \mathrm{P}$, and $\mathrm{K}$, which highest increase was achieved at a rate of $100 \%$ (initial concentration). This result is somewhat different from that concluded by [27] where up to the rate of $100 \mathrm{ppm}$ LOF, only $\mathrm{N}$ was significantly uptake by sweet corn while $\mathrm{P}$ and $\mathrm{K}$ uptakes were not affected. This might relate to total volume and method of LOF application. Research conducted previously using foliar application with total volume of only $600 \mathrm{ml}$ per plant. It is also observed from Figs. 1, 2, and 3 that no supplement and the highest rate of LOF exhibit higher increment in major nutrient uptakes indicated by the slope of regression line when soil is fertilized with higher rates of vermicompost. At lowest rate of LOF indicates that high response of sweet corn to vermicompost application while at the highest rate of LOF might be associated with higher easily degradable organic matter in soil from LOF leading to the fast availability of plant nutrients. Figs. 1, 2, and 3 also indicates that at all rates of vermicompost application, the supplement of LOF at the concentration of 25,50 and $75 \%$ did not provide different uptake of major nutrient by sweet corn. This strengthens the argument that addition of LOF exhibits good response on the uptake of major nutrient either at low or high concentration. Vermicompost application at rate $25 \mathrm{Mg} \mathrm{ha}^{-1}$ supplemented with $100 \%$ LOF provided highest uptakes of N, P, and K, suggesting that the combination was most effective 


\section{B. Growth of Sweet Corn}

The increase in major nutrient uptake after application of vermicompost combined with LOF was followed by improvement of growth of sweet corn as shown in Fig. 4. Application of vermicompost had a significant increase in plant height, plant leaf area, shoot fresh and dry weight of sweet corn. This result coincided to that concluded by [36] where shoot dry matter increased with increasing rates of poultry manure application. A similar trend was also detected in the application of LOF. An earlier study by [26] showed different result where the combination of $15 \mathrm{Mg} \mathrm{ha}^{-1}$ vermicompost and LOF rates did not have an effect on plant diameter, plant leaf area, root fresh weight, and shoot fresh weight but plant height. This is somehow associated with lower rate of vermicompost.

Sweet corn fertilized with $25 \mathrm{Mg} \mathrm{ha}^{-1}$ vermicompost supplemented with $100 \%$ LOF raised plant height, plant leaf area, shoot fresh weight and shoot dry weight by 11.1, 21.6, 28.9 , and $30.9 \%$, respectively as compared to that without supplementation and by $19.4,52.7,64.4$, and $49.5 \%$, respectively in comparison to that fertilized with $15 \mathrm{Mg} \mathrm{ha}^{-1}$ without addition of LOF (rate usually prepared by local farmer). This finding indicates that along with vermicompost fertilization, the addition of LOF during growth period provides the substantial improvement on sweet corn growth since nutrients will be available when required by the plant. The previous experiment indicated that $\mathrm{N}$ uptake by sweet corn drastically increased up to maximum growth then decreasing slowly afterward [37], suggesting high demand of plant nutrient during the growth period.

\section{Yield of Sweet Corn}

Vermicompost fertilization supplemented with LOF linearly raised diameter of the ear (Fig. 5) which was followed by an increase in weight of the husked ear. Liquid organic fertilizer linearly increased the length of the ear, but vermicompost fertilization did not influence the yield component (Table 1). This indicates that the weight of husked ear is more related to the diameter of the ear than the length of ear, meaning that LOF yielded greater ear. Bigger ear leads to the higher weight of unhusked ear and yield per plot. Increasing rates of vermicompost, as well as LOF, exhibited a higher diameter of the ear, the weight of husked ear, the weight of unhusked ear and yield per plot. The previous finding pointed out that treatment of LOF did not affect the weight of husked ear, the length of ear, and weight of unhusked ear [26] but other finding reported by [29] showed that LOF increased the length of ear, the diameter of ear and weight of the husked ear. The difference between the two findings is probably due to the difference in LOF sources.
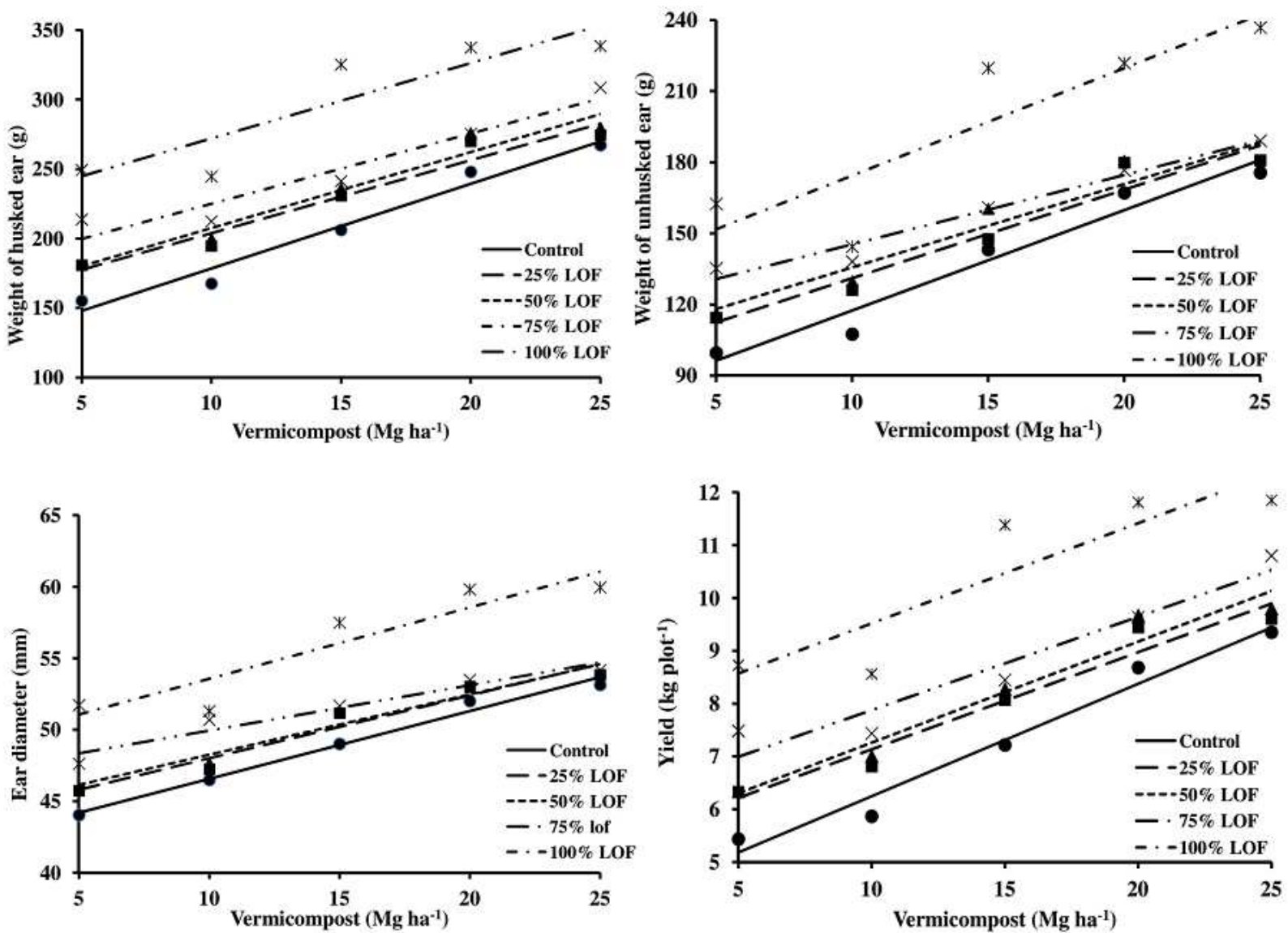

Fig. 5 Effects of vermicompost supplemented with LOF on diameter of ear, weight of husked ear, weight of unhusked ear and yield per plot 
Enhancement of sweet corn yield and its components is mainly associated with improvement of its growth. Pearson correlation analysis shows that weight of husked ear is significantly related to shoot fresh weight and shoot dry weight with coefficient correlation values of 0.95 and 0.78 , respectively as indicated in Fig. 6. This points out that shoot weight has pronounced contribution to increasing in sweet corn yield. Our finding also shows that weight of husked ear is positively correlated to $\mathrm{N}, \mathrm{P}$, and $\mathrm{K}$ uptakes by sweet corn with $\mathrm{r}$ values of $0.75,0.63$ and 0.81 , respectively. This result coincided with that reported by [38] where corn yield significantly related to macro and micro nutrients uptake.
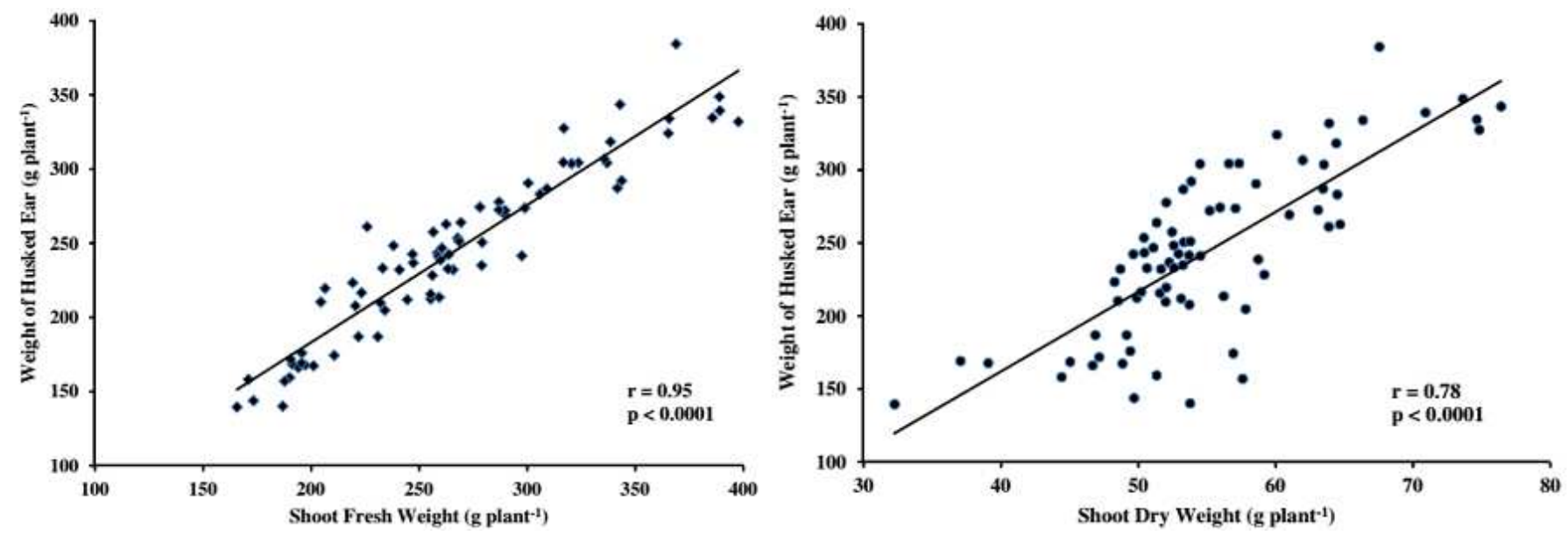

Fig. 6 Relationship between weight of husked ear with shoot weight of sweet corn

\section{CONCLUSIONS}

Vermicompost fertilization provided a distinct increase in growth and yield of sweet corn under organic farming system as indicated by enhancement of N, P, and K uptakes, plant height, plant leaf area, shoot weight, weight of husked and unhusked ear, diameter of ear as well as yield per plot but length of ear. So did the supplementation of LOF. Application of vermicompost at a rate of $25 \mathrm{Mg}$ ha- 1 supplemented with $100 \%$ LOF (initial concentration) resulted in greatest growth and yield of sweet corn, indicating that the fertilizer combination was the most effective complementary fertilization for sweet corn production under organic system. Shoot weight of sweet corn had a significant contribution to increasing of sweet corn yield. It is suggested that supplementation of LOF along with organic fertilization is necessary to enhance sweet corn production under the organic farming system.

\section{ACKNOWLEDGEMENT}

Deep appreciation is handed to Directorate General of Research and Extension, Ministry of Research, Technology and Higher Education for providing financial assistant through 2016 Fundamental Research Scheme. Extended thank also goes to CAPS Research Station, Faculty of Agriculture, the University of Bengkulu for providing experimental site and other necessary resources.

\section{REFERENCES}

[1] S. Savci, "An agricultural pollutant: Chemical fertilizer," Int. J. Environmental Science and Dev., vol. 3, pp. 77-80, 2012.

[2] P. Barak, , B. O. Jobe, A. R. Krueger, L. A. Peterson, and D. A. Leird, "Effects of long term soil acidification due to nitrogen fertilizer inputs in Wisconsin," Plant and Soil , vol. 19, no. 1, pp. 61-69, 1997.
[3] M. Ruark, L. Brundy, T. Andraski, and A. Peterson, "Fifty years of continous corn: Effects on soil fertility," Proc. Winconsin Crop Management Conference vol. 51, pp. 127-132, 2012.

[4] R. L. Mulvaney, S.A. Khan, and T.R. Elsworth, "Synthetic nitrogen fertilizers deplete soil nitrogen: A global dilemma for sustainable cereal production,” J. Environ. Qual., vol. 38, no. 6, pp. 2295-2314, 2009.

[5] S. Melero, E. Madejón, J. F. Herencia, J. C. Ruiz, "Effect of implementing organic farming on chemical and biochemical properties of an irrigated loamy soil," Agronomy Journal, vol. 100, no. 1, pp. 136-144, 2008.

[6] S. G. Ubierna, I. Jose-Mardomingo, B. Carrero-Gonzale, M. T. Cruze, and A. A. Casermeiro, "Soil organic metter evolution after the application of high doses of organic amendments in a Mediterranean calcareous soil," J. Soils Sediments, vol. 12, pp. 1257-1268, 2012.

[7] S. Canali, A. Trinchera, F. Intrigliolo, L. Pompili, L. Nisini, S. Mocali, and B. Torrisi, "Effect of long term addition of compost and poultry on soil quality of citrus orchards in Southern Italy," Bio Fertil Soils, vol. 40, pp. 206-210, 2004.

[8] M. M. Wander, W. Yun, W. A. Goldstein, S. Aref and S. A. Khan "Organic $\mathrm{N}$ and particulate organic matter fractions in organic and conventional farming systems with a history of manure application," Plant Soil vol. 291, pp. 311-321, 2007.

[9] P. Hepperly, D. Lotter, C. Z. Ulsh, R. Seidel, and C. Reider, "Compost, manure and synthetic fertilizer influences crop yields, soil .properties, nitrate leaching and nutrient content," Compost Sci. and Util., vol. 17, no. 2, pp. 117-126, 2009.

[10] R. G. Joergensen, P. Mäder and A. Fließbach, "Long-term effects of organic farming on fungal and bacterial residues in relation to microbial energy metabolism," Biol Fertil Soils vol. 46, pp. 303-307, 2010.

[11] Z. Muktamar, D. Putri, N. Setyowati, "Reduction of synthetic fertilizer for sustainable agriculture: Influence of organic and nitrogen fertilizer combination on growth and yield of green mustard," IJASEIT vol. 6 no. 3, pp. 361-364. 2016.

[12] K. Raphael and K. Velmourougane, "Chemical and microbiological changes during vermicomposting of coffee pulp using exotic (Eudrilus eugeniae) and native earthworm ( $\mathrm{P}$ "erionyx ceyanesis) species,” Biodegradation vol. 22, pp. 497-507, 2011.

[13] M. Tejada, I. Gomez, T. Hernandez, and C. Garcia, "Utilization of vermicomposts in soil restoration: Effects on soil biological properties," Soil Sci. Soc. Am. J., vol.74, pp. 525-523, 2010.

[14] T. T. Doan, T. Henry-des-Tureaux, C. Rumpel, J. L. Janeau, P. Jouquet, "Impact of compost, vermicompost and biochar on soil 
fertility, maize yield and soil erosion in Northern Vietnam: A three year mesocosm experiment," Sci. of the Total Env., vol. 514, pp. 147-154. 2015.

[15] H. D. Foth and B. G. Ellis, Soil Fertility, 2nd Ed. Lewis Publishers. Tokyo, 1997.

[16] E. P. Jouquet, E. Bloquel, T. T. Doan, M.Ricoy, D. Orange, C. Rumpel, and T. T. Duc, "Do compost and vermicompost improve macronutrient retention and plant growth in degraded tropical soils?" Compost Science \& Utilization vol. 19, no. 1, pp. 15-24, 2011.

[17] M. Y. Habteselassie, B. E. Miller, S. G. Thacker, and J. M. Stark, J. M. Norton, "Soil nitrogen and nutrient dynamics after repeated application of treated dairy-waste," Soil Sci. Soc. Am. J., vol. 70, no. 4, pp. 1328-1337, 2006

[18] Y. Sastro and I. P. Lestari, "The growth and yield of sweet corn fertilized by dairy cattle effluents without chemical fertilizer in Inceptisol," J. Trop Soils, vol. 16, no. 2, pp. 139-143, 2011

[19] N. F. Rizqiani, E. Ambarwati, and N.W. Yuwono, "The effect of dosage and frequence of liquid organic fertilizer on growth and yield of lowland benas (Phseolus vulgaris L.)," Jurnal Ilmu Tanah dan Lingkungan vol. 7, no. 1, pp. 43-53, 2007. (in Indonesian).

[20] Z. Muktamar, S.Y.K. Hasibuan, D. Suryati, and N. Setyowati, "Column study of nitrat downward movement and selected soil chemical properties' changes in mine spoiled soil as influenced by liquid organic fertilizer," J. Ag Tech. vol. 11, no. 8, pp. 2017-2027, 2015.

[21] W. E. Jokela, J.H. Grabber, D.L. Karlen, T.C. Balser, and D. E. Palmquist, "Cover crop and liquid manure effects on soil quality indicators in corn silage system," Ag. Journal vol. 101, no. 4, pp. 727-737, 2009.

[22] Fahrurrozi, Z. Muktamar, N. Setyowati, S. Sudjatmiko, and M. Chozi, "Eavaluation of tithonia-enriched liquid organic fertilizer for organic carrot production," J. Ag. Tech. Vol. 11 no. 8, pp. 1705-1712.

[23] E. C. Enujeke, I.M. Ojeifo. G.U. Nnaji, "Effects of liquid organic fertilizer on time of tsselling, time of silking and grain yield of maize (Zea mays)," Asian J. Agric. and Rural Dev., vol. 3, no. 4, 186-192, 2013.

[24] A.Rahmi and Jumiati, "Pengaruh pupuk organik cair super AC1 terhadap pertumbuhan dan hasil jagung manis," Agritrop. vol. 26, no. 3, pp. 105-109, 2007 (in Indonesian)

[25] A.Ramah, M. Izzati, and S. Parman, "Pengaruh pupuk organik cair berbahan dasar limbah sawit putih (Brassica chinensis L.) terhadap pertumbuhan tanaman jagung manis (Zea mays L. Var. Saccharata)," Buletin Anatomi dan Fisiologi vol. 12, no. 1, pp. 65-71, 2014. (in Indonesian).
[26] Fahrurrozi, Z. Muktamar, Dwatmadji, N. Setyowati, S. Sudjatmiko, and M. Chozin, "Growth and yield responses of three sweet (Za mays L. Var. Saccharata) varieties to local based organic fertilizer," IJASEIT vol. 6, no. 3, pp. 319-323, 2016

[27] Z. Muktamar, Fahrurrozi, Dwatmadji, N. Setyowati, S. Sudjatmiko, and M. Chozin, :Selected macro nutrients' uptake by sweet corn under different rates of liquid organic fertilizer in closed agriculture system," IJASEIT vol. 6, no. 2, pp. 258-261, 2016.

[28] F. Ling, and M. Silberbus, "Response of maize to foliar vs. soil application of nitrogen-phosphorus-potassium fertilizers," J. Plannt Nut., vol. 25, no. 11, pp. 2333-2342, 2002.

[29] E. E. Schulte and K.A. Kelling, "Plant Analysis: a Diagnostic tool. National Corn Handbook Crop Fertilization," www.extension.purdue.ed/extmedia/nch/nch-46.html. 2015.downloded 25 March 2015.

[30] A.L. Wright, T. L. Provin, F.M. Hons, D.A. Zubere, and R.H. White, "Compost source and rate effects on macronutrient availability under Saint Augustine Grass and Bermuda Grass Turf," Compost Sci. and Util., vol. 15 , no. 1, pp. 22-28, 2007.

[31] V. A. Laudicina and L. Badalucco, "Effects of compost input and tillage intensity on soil microbial biomass and activity under Mediterranean condition," Biol Fertil Soils, vol. 47, pp. 63-70, 2011.

[32] D. E. Kaiser, A. P. Mallarino, and M. Bermudez, "Corn grain yield, early growth, and early nutrient uptake as affected by broadcast and in-furrow starter fertilization,” Agron. J. vol. 97, no. 2, pp. 620-626, 2005 .

[33] A.B. Leytem, R. S. Dungan, and A. M. Moore, "Nutrient availability to corn from dairy manures and fertilizer in a calcareous soil," Soil Sci. vol. 176, no. 9, pp. 1-9, 2011.

[34] A.J. Sindelar, J. A. Lamb, C. C. Sheaffer, C. J. Rosen, and H. G Jung, "Fertilizer nitrogen rate effects on nutrient removal by corn stover and cobs," Agron. J. vol. 105, no. 2, pp. 437-445, 2013.

[35] E. C. Enujeke, Nutrient content (\% dry matter) of maize as affected by different levels of fertilizers in Asaba Area of Delta State. Sustainable Agriculture Research vol. 2, no. 3 pp: 76-85, 2013.

[36] H. A. Akintoye and A. B. Olaniyan, "Yield of sweet corn in response to fertilizer sources," J. Ag. Science vol. 1, no. 5, pp. 110-116, 2012.

[37] L. Zotarelli, J. M. Scholberg, M. D. Dukes, and R. Munoz-Carpena "Fertilizer residence time affects nitrogen uptake efficiency and growth of sweet corn," J. Environ. Qual., vol. 37, pp. 1271-1278, 2008 .

[38] J. R. Heckman, J. T. Sims, D. B. Beegle. F. J. Coale, J. S. Herbert, T W. Bruulsema, and W. J. Bamka, "Nutrient removal by corn grain harvest," Agron J. vol. 95, no. 3, pp. 587-591, 2003. 